\title{
Transcriptional, post-transcriptional and epigenetic control of porcine oocyte maturation and embryogenesis
}

\author{
R.S. Prather', J.W. Ross' ${ }^{2}$, S. Clay Isom ${ }^{1}$ and J.A. Green ${ }^{1}$ \\ 'Division of Animal Sciences, University of Missouri, Columbia, MO 65211, USA and \\ ${ }^{2}$ Department of Animal Science, lowa State University, Ames, IA 50011, USA
}

\begin{abstract}
Embryogenesis is a complex process that is controlled at various levels. As new discoveries are made about molecular mechanisms that control development in other species, it is apparent that these same mechanisms regulate pig embryogenesis as well. Methylation of DNA and modification of histones regulate transcription, and mechanisms such as ubiquitinization, autophagy and microRNAs regulate development post-transcriptionally. Each of these systems of regulation is highly dynamic in the early embryo. A better understanding of each of these levels of regulation can provide tools to potentially improve the reproductive process in pigs, to improve methods of creating pig embryos and cloned embryos in vitro, and to provide markers for predicting developmental competence of the embryo.
\end{abstract}

\section{Introduction}

Development of the embryo and the relative likelihood that it will give rise to a viable offspring is dependent upon factors that include, but are not limited to, the general health status of the sire and dam during gametogenesis and their genetic contributions. These factors set the stage for the oocyte to mature with the proper stores of information to support complete development. Factors that regulate development will be presented with a focus on transcriptional, post-transcriptional and epigenetic regulation of development in the pig. Finally, examples of how this information can be used to our advantage will be presented.

\section{Overview of embryogenesis}

An oocyte competent to develop to term is the result of adequate growth of the oocyte, and subsequent nuclear and cytoplasmic maturation. During this time the information necessary for early development is transcribed and stored in the form of RNA, or translated and stored in the form of protein. Upon germinal vesicle breakdown (GVBD) transcription ceases and nuclear maturation progresses until arrest at metaphase II of meiosis. Fusion of the sperm and oocyte plasma membrane results in the deposition of the sperm chromatin in the ooplasm, and resumption and completion of meiosis of the maternal chromatin. The maternally-and paternally-derived chromatin each forms a separate pronucleus that migrates to the center of the oocyte. At first mitosis the pronuclear envelopes breakdown and for the first time the maternally-and paternally-derived chromatin mix as the chromosomes align on the metaphase plate and subsequently segregate to the two poles prior to cytokinesis. In the pig, after the first mitosis the embryo immediately begins DNA synthesis without a G1 phase. After DNA 
synthesis is completed (about 12 hours (Prather et al. 1996)) the embryo enters directly into mitosis without an intervening G2 phase. Entry into the 4-cell stage is the first time that a G1 phase is inserted and corresponds with the onset of transcription (Schoenbeck et al. 1992). The length of the 4-cell stage is over twice that of the 2-cell stage; the difference being the result of a short G1 phase and a long G2 phase (Anderson et al. 2001). When the chromatin is not encumbered with DNA polymerases, i.e. $G 1$ and $G 2$, the transcriptional machinery can gain access to the chromatin and RNA can be synthesized (Prather 1993).

Since there is little or no transcription between GVBD and the 4-cell stage, it is imperative that the germinal vesicle stage oocyte (GV) be poised to control development for the first few divisions. Thus, the information stored in the oocyte must be sufficient to direct the first few cellular divisions and establish the correct chromatin configuration so that the symphony of gene expression can begin. If the chromatin configuration is not correct, the embryo may develop to varying degrees, but it may not have normal transcription (Tian et al. 2009) or it may not thrive and reproduce - as observed with some cloned animals (Carter et al. 2002). Thus it is imperative that the correct developmental pattern of gene expression be established during the first few cleavage divisions.

Upon successful activation of the embryonic genome (ZGA) the pig embryo continues to divide to the 8-, 16- and subsequently the 32-cell stage. Compaction of the blastomeres occurs during this time and the embryo continues the differentiation process by forming a blastocyst with two distinct cell types, each with its own transcriptional repertoire. Dramatic changes in mRNA abundance occur between the oocyte and 4-cell stage and blastocyst stage and these changes are driven by both transcriptional and post-transcriptional regulation (Whitworth et al. 2005).

\section{Transcriptional regulation}

Mammalian oogenesis, oocyte maturation and early embryo development are distinct processes, each car efully coordinated, and bound by a common thread: the need to supply an appropriately programmed genome that permits proper gene expression in time and space. In addition to transcription factor binding to promoters, regulation of transcription early in development is achieved via epigenetic mechanisms. The term epigenetics, as used and accepted today, is defined as "heritable changes in gene function that cannot be explained by changes in DNA sequence" (Russo et al. 1996). Epigenetic mechanisms in the oocyte and early embryo include DNA methylation, histone modification, chromatin remodeling, and non-coding RNAs (nCRNA) (Li 2002; Morgan et al. 2005). Space limitations prevent a thorough treatment of each of these topics. Rather a brief summary of the status of our collective understanding of how these mechanisms are/could be involved in controlling transcription in the mammalian oocyte and early embryo will be provided. Most of the information will focus on porcine embryo development.

Methylation of the cytosine of $\mathrm{CpC}$ dinucleotides plays a central role in transcriptional regulation in mammals. In most situations, methylation of DNA in and near genes is associated with repression of transcriptional activity of those genes (lager et al. 2008). DNA methyltransferases are responsible for establishing (DNMT3a and DNMT3b) and maintaining (DNMT1) methylation patterns within DNA (Li 2002). Interestingly, mRNA levels for DMNT1 are 20-fold higher in the pig GV oocyte to 4-cell stage as compared to the blastocyst stage, whereas DMNT3b levels are not different (Whitworth et al. 2005). Four general mechanisms have been proposed for the methylation-mediated silencing of gene expression: 1) direct inhibition of transcription factor binding of methylated gene promoter regions; 2 ) recruitment of co-repressors to methylated regions by DNA methyl-binding proteins; 3) DNA methyltransferase-mediated chromatin 
remodeling; and 4) dampened efficiency of transcriptional elongation in methylation-rich gene bodies. A detailed summary of these mechanisms has been reviewed (Klose \& Bird. 2006).

It has become apparent in recent years that, in addition to DNA methylation, histone modification plays an important role in controlling gene expression in both gametes (Dejong 2006) and early embryos (Nowak-Imialek et al. 2008; Ooga et al. 2008; Thomas et al. 2008). Nuclear DNA is packaged in the cell as chromatin - octamers of predictably-organized histone proteins wrapped by $146 \mathrm{bp}$ of DNA. The $\mathrm{N}$-termini of the histone proteins are highly susceptible to post-translational modifications, including (but not limited to) lysine acetylation, lysine and arginine methylation, serine and threonine phosphorylation, sumoylation, ubiquitination and ADP-ribosylation (Kouzarides 2007). The effects of histone modifications on gene expression may not be predictable enough to consider these patterns of modifications as a "code" in the truest sense, as once proposed (Strahl \& Allis 2000). Rather it seems that genomic and physiologic context play a significant role in determining the effect that individual modifications might have on chromatin function. Some generalizations can be made: histone acetylation is almost universally associated with increased transcription; methylation of lysine residues can either activate ( $\mathrm{H} 3 \mathrm{~K} 4 \mathrm{me}, \mathrm{H} 3 \mathrm{~K} 36 \mathrm{me}, \mathrm{H} 3 \mathrm{~K} 79 \mathrm{me}$ ) or repress (H3K9, H3K27, H4K20) transcription; while histone ubiquitination and sumoylation are generally considered to be repressive to transcription. Control over histone modifications is exquisite, with an impressive array of enzymes dedicated to establishing, maintaining and/or removing histone marks (Kouzarides 2007).

In addition to these primary marks, there are a number of facilitator processes and molecules that are involved in the establishment, maintenance, and transmission of epigenetically silenced (or activated) genes. These include polycomb group ( $\mathrm{PcG}$ ) proteins, trithorax group ( $\operatorname{Tr} \times \mathrm{G}$ ) proteins, chromatin remodeling complexes, and ncRNAs. Polycomb group and TrxG proteins function essentially antagonistically to repress or maintain activity of genes that are important during development. Some members of the PCG and TrxG protein families have histone methyltransferase activities, with $\mathrm{PCG}$ proteins methylating $\mathrm{K} 27$ of $\mathrm{H} 3-$ a generally repressive mark - and TrxG proteins catalyzing $\mathrm{H} 3 \mathrm{~K} 4$ methylation, which is permissive to transcription (Kiefer 2007). Chromatin remodeling complexes (de la Serna et al. 2006) such as the ISWI and various SWI/SNF complexes interact with and modulate the activity of histone arginine methyltransferases ( $\mathrm{Pal} \&$ Sif. 2007) and acetyltransferases (Brockmann et al. 2001) which are generally associated with increased transcription. These complexes are necessary for transcriptional regulation that occurs after fertilization (de la Serna et al. 2006). SMARCA4, an SNF2 chromatin remodeling ATPase, is an important determinant of early porcine embryogenesis in both in vitro-fertilized and somatic cell nuclear transfer (SCNT) embryos (Magnani et al. 2008). Finally ncRNAs result in gene silencing in a variety of scenarios important to development, such as X-chromosome inactivation (Boumil \& Lee. 2001) and gene imprinting (Nagano et al. 2008; Pandey et al. 2008), in addition to their role in RNA-induced gene silencing (RNAi).

Almost by definition, cellular differentiation is an epigenetic phenomenon: phenotypic and functional differences between cell types arise without reordering the sequence of the DNA. Thus for each distinct cell population, there is an associated cadre of epigenetic modifications that determine which genes are turned on/off thus giving each cell population its phenotype. As somatic cells differentiate into germ cells, somatic-specific epigenetic marks are erased and at the end of gametogenesis there is a paternal-specific pattern of epigenetic modifications established in each sperm, and a maternal-specific pattern established in each oocyte. Upon fertilization, the genome of the embryo is demethylated and otherwise reprogrammed to replace the extensive germ cell-specific epigenetic marks with those conducive to pluripotency. De novo reestablishment of epigenetic marks in appropriate cell lineage-specific patterns occurs 
in the inner cell mass (ICM) and to a lesser extent in the trophectoderm of the blastocyst (Dean et al. 2001; Santos et al. 2002). A global survey of DNA methylation during early development in the pig showed that $18 \%$ of the randomly selected genomic regions changed from the gametes to the blastocyst stage (Bonk et al. 2007a). Some DNA methylation in early embryos is sensitive to the culture conditions, i.e. cultured embryos can have a different pattern of DNA methylation compared to in vivo-collected embryos (Mann et al. 2003; Mann et al. 2004).

Expression of imprinted genes- genes that are expressed in a parent-of-origin, monoallelic pattern - show how epigenetics can impact development. Many imprinted genes regulate fetal and placental growth, development, and function. Establishment of imprinting appears to be fairly conserved across species, and one such imprinted region is the well-characterized IGF2/H19 locus (Sasaki et al. 2000; Engel et al. 2004), which in most mammalian species including pig (Han et al. 2008) - is heavily methylated on the paternal allele, and relatively unmethylated on the maternal allele. In the mouse the unmethylated maternal allele can bind to an insulator (CTCF) which prevents the IGF2 promoter from interacting with an upstream enhancer, thus preventing maternal allele expression of IGF2. An inactive IGF2 allele is conducive to $\mathrm{H} 19$ expression and is therefore expressed highly from the maternal chromosomes. Heavy methylation on the paternal allele is repressive to $\mathrm{H} 19$ expression, while conducive to IGF2 expression because the CTCF insulator does not bind to methylated DNA. Another imprinted locus is IGF2R/KCNQ1, which is silenced at the paternal allele by the interaction of ncRNAs with histone methyltransferases and members of the PCG complex (Nagano et al. 2008; Pandey et al. 2008). While the sperm and oocyte chromatin are hypermethylated relative to the early embryo, the demethylation that occurs after fertilization does not result in a loss of the imprint (Nakamura et al. 2006; Santos et al. 2002). The mechanisms by which these epigenetic 'memories' are maintained are poorly understood, but additional examples of how epigenetic mechanisms impact development are abundant (Hansen et al. 2008). For example, increased methylation of arginine residues on histone $\mathrm{H} 3$ predisposes blastomeres of the early embryo to contribute to the pluripotent cells of the ICM, whereas lower levels of $\mathrm{H} 3$ arginine methylation direct cells to a mural trophectoderm state (Torres-Padilla et al. 2007). Histone methyltransferase EHMT2 is a 'master regulator' of early embryonic genes: 126 genes (including POU 5F1) expressed in undifferentiated mouse embryonic stem cells were converted to heterochromatin and silenced by EHMT2 upon differentiation (Epsztejn-Litman et al. 2008). A common mark on these gene promoters was trimethylation on lysine 9 of histone H3. Interestingly, the promoters of these 126 silenced genes exhibited de novo DNA methylation in addition to the $\mathrm{H} 3 \mathrm{~K} 9$ trimethylation. This case also serves to exemplify the functional interplay that exists between these supposed 'separate' mechanisms of epigenetic gene control, in that EHMT2 - a histone methyltransferase - also appears to be able to direct de novo DNA methylation by autonomously recruiting DNA methyltransferases to the silenced loci.

Much of what we know about epigenetic control of gene activity in germ cells and early embryo development comes from studies investigating the nuclear reprogramming associated with SCNT. The inefficiency of SCNT has been correlated with aberrant patterns of DNA methylation, histone modification and, consequentially, gene expression (Santos et al. 2003; Wrenzycki et al. 2006; Bonk et al. 2007b). Upon transfer of a somatic nucleus into oocyte cytoplasm an epigenetic reprogramming event must take place to revert the somatic chromatin back to a pluripotent-like state. This is an inefficient process, with the transferred nucleus often retaining a proportion of the somatic epigenetic marks, resulting in mis-regulated gene expression, which in turn can cause abnormalities in the embryo or fetus (Niemann et al. 2002). The most severe of these abnormalities result in failed development very early. However, less severe epigenetic aberrations can allow development to proceed, but often the resulting offspring have obvious 
deformities and/or are compromised physiologically after birth. The term Large Offspring Syndrome (LOS) was coined as a result of the large birth weights of cloned calves, although the characterization of this syndrome as dealing exclusively with "Large Offspring" is inappropriate since cloned offspring in some species (e.g. pigs) tend to have lower birth weights relative to their naturally-conceived counterparts (Estrada et al. 2007); additional manifestations of LOS include hydroallantois, hydrops fetalis, hyperplasia in various organ systems, compromised immune function, respiratory distress and other skeletal and soft tissue deformations (Carter et al. 2002; Wrenzycki \& Niemann 2003; Carroll et al. 2005; Wrenzycki et al. 2006). Of interest is the association of similar developmental defects with offspring arising from other less invasive assisted reproductive technologies such as in vitro-oocyte maturation, -fertilization, -culture, and intracytoplasmic sperm injection (Farin et al. 2006; Fernandez-Gonzalez et al. 2007; Lawrence \& Moley. 2008). While the etiology of these disturbances is not known it is clear that epigenetics play a role. In one recent study, bisulfite sequencing at distinct genomic loci revealed significant differences in levels of DNA methylation in comparisons made between in vivo-produced and parthenogenetic blastocysts (5/12 loci were differentially methylated), and between in vitro fertilized blastocysts (6/8 loci) and SCNT blastocysts (4/12 loci) (Bonk et al. 2007a). Success at increasing 'normal' developmental patterns of cloned embryos is achievable by treating donor cells and/or reconstructed embryos with inhibitors of DNA methylation and histone acetylation (Ding et al. 2008; lager et al. 2008). It has yet to be demonstrated whether such treatments can restore 'normal' transcription profiles in cloned embryos, or reduce the occurrence or severity of LOS.

The study of the epigenetic control of embryonic and germ cell transcription is a nascent field of research. What has emerged is a picture of enormous complexity as there is significant functional overlap and cooperation between marking mechanisms. The practical application of this knowledge is now beginning to be developed. This will be an area of intense interest into the foreseeable future, with continued emphasis being placed on the epigenetic control of development, and especially pluripotency.

\section{Post-transcriptional regulation}

In addition to proper chromatin configuration, many maternally-derived RNAs and proteins must be degraded by microRNAs or the binding of regulatory proteins to the 3' untranslated region of the message (Schier 2007; Stitzel \& Seydoux 2007). Degradation of the maternal proteins begins immediately after fertilization and is mediated partially via ubiquitin-proteasome mediated processes (Huo et al. 2004) and macroautophagy. There are at least two periods of degradation; the first is at the time of fertilization, and the second is at the time of ZGA. In drosophila the main degradation of transcripts and proteins occurs at ZGA and a third of the genes whose maternal transcripts are degraded also begin transcription at the same time (De Renzis et al. 2007).

Macroautophagy results from the sequestration of proteins into an autophagosome that fuses with a lysosome where the proteins are degraded (Mizushima et al. 2008). This system, mediated by autophagy-related 5 protein (ATC5), is up-regulated after fertilization or parthenogenetic activation in the mouse, and a deficiency in this system results in embryos that die by the 4- to 8-cell stage (Tsukamoto et al. 2008). In the pig, ATG5 (aka APG5L) decreases $(p=0.080)$ from a ratio of 10.2 in the GV to 3.5 at the 4-cell stage, and then decreases further to 1.3 by the blastocyst stage (Whitworth et al. 2005). High levels of mRNA for ATG5 show that a macroautophagy system may also function in the pig. 


\section{MicroRNA regulation of oocyte maturation and embryonic development}

Specificity in cellular phenotype, as affected by differentiation and cellular lineage, is the result of a particular combination mRNA transcript abundance and controlled translation of those mRNAs to produce proteins capable of eliciting biological function. Transcription and translation are both critical for specificity in cellular phenotype and miRNAs have been shown to be potent regulators of transcript abundance and protein translation, particularly during cell lineage progression and differentiation (Neilson et al. 2007).

\section{What are miRNAs?}

MicroRNAs are ncRNA that are processed into a functional size of 18-24 nucleotides (Bartel 2004). The mature sequence confers significant biological impact on the cells in which they are synthesized and processed through perfect or imperfect pairing to the 3'UTR of a target mRNA. The binding of a miRNA and its target mRNA $3^{\prime} U T R$ results in posttranscriptional gene silencing (PTCS) through the action of several mechanisms, including translation inhibition, target transcript degradation and in some cases, chromatin silencing via methylation (Jackson \& Standart 2007). Since the discovery of the first miRNA (Lee et al. 1993; Wightman et al. 1993) significant advancements have been made into the understanding of miRNA prevalence, biogenesis and function in the Plantae and Animalia kingdoms, largely due to the overlapping pathways and mechanisms involved with RNA interference (RNAi). Current estimates predict that $2-3 \%$ of human genes represent miRNAs which are collectively capable of conferring PTCS on an estimated $30 \%$ of the human genome (Rajewsky 2006).

\section{MicroRNA biogenesis}

Similar to mRNA transcription, microRNA expression is RNA polymerase It dependent (Bartel 2004). The capped, polyadenylated RNA transcripts containing the primary miRNA, have been coined 'pri-miRNA' (Lee et al. 2002). All pri-miRNAs have the spatial sequence complementation necessary to form secondary hairpin structures that are recognized by nuclear RNASEN (aka Drosha RNase III endonuclease) (Lee et al. 2003). RNASEN cleavage, which requires the functional cooperation of DGCR8 (Han et al. 2004), results in the nuclear release of $\sim 60-70$ nt stem loops, referred to as pre-miRNA (Lee et al. 2002; Zeng \& Cullen 2003). Following RNASEN/DGCR8-mediated cleavage, pre-miRNAs are exported from the nucleus (Lund et al. 2004) into the cellular cytoplasm, DICER1, also an RNase III endonuclease, typically cleaves both strands resulting in 18-24 nt dsRNA molecules possessing 3' overhangs. These molecules are referred to as mature microRNAs (Grishok et al. 2001; Hutvagner et al. 2001; Ketting et al. 2001). Argonaute proteins (EIF2C1) then interact with mature miRNAs as the foundational component to the formation of a RNA-induced silencing complex (RISC) capable of conferring PTGS (Liu et al. 2008).

\section{MicroRNA mechanism of action}

The mechanism of action of microRNAs was demonstrated when the abundance of lin-4, having sequence complementary to lin-14 and lin-28, was shown to be involved with $\mathrm{C}$. elegans larval stage transition from L1 to late L2/early L3 (Lee et al. 1993; Wightman et al. 1993). During this developmental transition both $\mathrm{LIN}-14$ and LIN-28 abundance was reduced 90 percent while mRNA abundance of lin-14 was unchanged compared to only a $50 \%$ reduction of $\mathrm{lin}-28$ 
mRNA (Seggerson et al. 2002). Both transcriptional degradation and translational repression are widely involved in miRNA function. In addition, targeted deadenylation, which accelerates mRNA decay, also occurs (Zhang et al. 2007). MicroRNA target recognition occurs primarily through the binding of residues on the $5^{\prime}$ end of the miRNA to complementary sequence in the 3'UTR of mRNA target for PTGS (Brennecke et al. 2005).

\section{Biological importance of miRNAs}

The biological importance of miRNA function is the suggested role of conferring robustness to a given cell's mRNA and protein profile (Stark et al. 2005) and is accomplished by providing alternative molecular networks that can contribute to the mRNA abundance and protein production. With respect to embryogenesis, miRNA functions are strategically involved with cell fate and are required for cell lineage destinations. This is evidenced by the tissue specificity of many miRNAs and is further supported by the fact that genes associated with tissue specific Gene Ontology (GO) categories have 3'UTRs enriched for miRNA binding sites whereas genes associated with non-tissue specific GO categories lack significant miRNA complementation sites in the $3^{\prime} U T R$ (Beuvink et al. 2007; Kawahara et al. 2007; Wang et al. 2007; Zhao et al. 2007).

Importance of miRNA function for oocyte and early embryonic development

Successful embryonic development in mammals requires broad translational arrest and mRNA clearance to deplete maternally derived mRNAs and proteins in coordination with ZGA and protein production; as shown in the pig (Schoenbeck et al. 1992). Maternal depletion of mRNA is in part controlled via the 3'UTR of the expressed transcripts (Brevini et al. 2007). So it is not surprising that differential expression of microRNAs is temporally associated with oocyte maturation and early embryonic development in a variety of species (Biemar et al. 2005; Watanabe et al. 2005; Giraldez et al. 2006; Tang et al. 2007).

The 3'UTR repertoire of the mRNAs present in porcine oocytes suggests a potential role during oocyte maturation and embryonic development. In addition the presence of DICER1 mRNA in GV oocytes at 2.3 times the abundance after ZGA suggests biological importance (Whitworth et al. 2005). Biological importance of DICER 1 is demonstrated by the ability of long double-stranded RNAs injected into porcine zygotes to induce knockdown of corresponding target mRNA (Cabot \& Prather. 2003). The required role of DICER1 function for successful development (Tang et al. 2007) suggests that specific mature miRNAs are responsible for PTGS necessary for embryo survival. While the average miRNA is estimated to have recognition sites for approximately 100 target mRNAs, specific individual miRNAs have the predicted ability to confer PTGS on a group of genes varying from only a few to more than 800 (Rajewsky 2006). Thus the alteration of only a few miRNA during embryonic development may contribute to large changes in transcript abundance during developmental progression or between embryo production methods (Whitworth et al. 2005). The loss of developmental capacity in mouse oocytes lacking functional DICER1 during oogenesis is associated with disorganized spindles, lack of chromosome alignment, as well as transcriptome and proteome alterations (Tang et al. 2007) . In addition to DICER 1 function being required for oocyte maturation and fertility, the maternal expression of EIF2C1, an RNA binding protein essential to the formation of RNA-induced silencing complexes, is required for early embryonic development in the mouse (Lykke-Andersen et al. 2008). Loss of function of EIF2C1 results in the stabilization of specific maternal mRNAs and arrested development during ZGA. EIF2C1 mRNA levels in the pig GV oocyte are 10- to 13-fold higher than in a reference sample (Whitworth et al. 2005) 


\section{The utility of understanding transcript population changes during embryo development}

At least three major benefits are derived from understanding alterations in transcript abundance in the early embryo. The first is the possibility that such information can be used to improve reproduction by explaining the $-30 \%$ loss of potential conceptuses that occurs during the first month of development. Toward that end, we have been engaged in EST projects to identify genes in reproductive tissues and early embryos of pigs (liang et al. 2001; jiang et al. 2004; Whitworth et al. 2004). Through these efforts many tissue-specific and novel (previously uncharacterized) genes were identified. Follow-up transcriptional profiling experiments with cDNA microarrays confirmed the involvement of many of these genes in embryo development, as well as providing a better understanding of the genetic pathways that are involved in embryo development (Whitworth et al. 2005). Secondly, such information can provide clues to improve assisted reproductive technologies, such as altering culture conditions to improve fertilization parameters (Hao et al. 2006). A third benefit is the opportunity to identify gene products that are predicted to be secreted into the culture medium. If such products happen to be correlated with developmental competence, they provide a potential means to non-invasively screen in vitro produced embryos to better define their quality.

Identification of transcribed genes that encode secreted molecules that are higher in in vivo produced embryos compared to in vitro produced embryos (Whitworth et al. 2005) may permit identification of molecule(s) that could be correlated with developmental completence. Several abundant and/or differentially transcribed genes were identified that are candidate markers because many:

- possess enzymatic activity that can be detected (e.g. PAGs, cathepsin D and ADAMs),

- possess enzyme inhibitory activity (e.g. Bikunin) that can be quantified,

- possess a defined biological activity that can be measured (e.g. IFN-gamma),

- exhibit relatively specific binding characteristics that might be exploited (e.g. Galectin 1 and (GFBP7), and

- $\quad$ are known to be bound by antibodies (e.g. CD9 antigen, Relaxin, Laminin receptor) that could be used to measure marker release.

Our group is currently working to determine if the data generated from transcriptional profiling can be leveraged to identify markers, such as those above, that can serve as way to identify embryos with low or high developmental potential (e.g. Telugu et al. 2009).

\section{Conclusion}

Control of development through the cycle of embryonic cells to somatic and germ celis is incredibly complex. Early thought was focused on transcriptional control of development. Now we have learned that transcriptional control is just one component. The factors that regulate transcription are very complex (histone modifications, DNA methylation) and post-transcriptional controls (miRNAs) appear to be just as important as transcriptional regulation alone. Nevertheless, a more complete understanding of the global control of differentiation will provide tools to improve the efficiency of in vivo processes. These efforts will also lead to improvements in systems of embryo production and will likely lead to the identification of factors that can be used to predict the developmental competence of embryos and gametes. 


\section{Acknowledgements}

The authors wish to acknowledge the support of the National Institutes of Health through the National Center for Research Resources (RR018877, RR013438), the USDA NRI (2006-35203-17282, 2004-35205-15549, 2008-35205-05309), and Food for the $21^{\text {si }}$ Century at the University of Missouri.

\section{References}

Anderson JE, Matteri RL, Abeydeera LR, Day BN \& Prather RS 2001 Degradation of maternal Cdc25c during the maternal to zygotic transition is dependent upon embryonic transcription. Molecular Reproduction \& Development 60 181-188.

Bartel DP 2004 MicroRNAs: genomics, biogenesis, mechanism, and function. Cell 116 281-97.

Beuvink I, Kolb FA, Budach W, Garnier A, Lange J, Natt F, Dengler U, Hall J, Filipowicz W \& Weiler J 2007 A novel microarray approach reveals new tissue-specific signatures of known and predicted mammalian microRNAs. Nucleic Acids Research 35 e52.

Biemar F, Zinzen R, Ronshaugen M, Sementchenko V, Manak JR \& Levine MS 2005 Spatial regulation of microRNA gene expression in the Drosophila embryo. Proceedings of the National Academy of Sciences of the United States of America $10215907-15911$.

Bonk Al, Cheong HT, Li R, Lai L, Hao Y, Liu Z, Samuel M, Fergason EA, Whitworth KM, Murphy CN, Antoniou E \& Prather RS 2007b Correlation of developmental differences to the methylation profiles of nuclear transfer donor cells. Epigenetics 2 179-186.

Bonk A], Li R, Lai L, Hao Y, Liu Z, Samuel M, Fergason EA, Whitworth KM, Murphy CN, Antoniou E \& Prather RS 2007a Aberrant DNA methylation in porcine in vitro-, parthenogenetic-, and somatic cell nuclear transfer-produced embryos. Molecular Reproduction \& Development 75 250-264.

Boumil RM \& Lee IT 2001 Forty years of decoding the silence in $\mathrm{X}$-chromosome inactivation. Human Molecular Genetics 10 2225-2232.

Brennecke J, Stark A, Russell RB \& Cohen SM 2005 Principles of microRNA-target recognition. Plos Biology 3 e85.

Brevini TA, Cillo F, Antonini S, Tosetti V \& Gandolfi F 2007 Temporal and spatial control of gene expression in early embryos of farm animals. Reproduction, Fertility \& Development $1935-42$.

Brockmann D, Lehmkuhler O, Schmucker U \& Esche H 2001 The histone acetyltransferase activity of PCAF cooperates with the brahma/SW/2-related protein BRG- 1 in the activation of the enhancer $A$ of the MHC class I promoter. Gene 277 111-120.

Cabot RA \& Prather RS 2003 Cleavage stage porcine embryos may have differing developmental requirements for Karyopherins alpha 2 and alpha 3. Molecular Reproduction and Development 64 292-301.

Carroll JA, Carter DB, Korte SW \& Prather RS 2005 Evaluation of the acute phase response in cloned pigs following a lipopolysaccharide challenge. Domestic Animal Endocrinology 29 564-572.

Carter DB, Lai L, Park KW, Samuel M, Lattimer JC, Jordan KR, Estes DM, Besch-Williford C \& Prather RS 2002 Phenotyping of transgenic cloned pigs. Cloning and Stem Cells 4 131-145.

de la Serna IL, Ohkawa Y, Higashi C, Dutta C, Osias J, Kommajosyula N, Tachibana T \& Imbalzano AN 2006 The microphthalmia-associated transcription factor requires SWISNF enzymes to activate melanocytespecific genes. Journal of Biological Chemistry 281 20233-20241.

De Renzis S, Elemento O, Tavazoie S \& Wieschaus EF 2007 Unmasking activation of the zygotice genome using chromosomal deletions in the Drosophila embryo. PLoS Biology 5 1036-1051.

Dean W, Santos F, Stojkovic M, Zakhartchenko V, Walter J, Wolf E \& Reik W 2001 Conservation of methylation reprogramming in mammalian development: Aberrant reprogramming in cloned embryos. Proceedings of the National Academy of Sciences of the United States of America 98 13734-13738.

Delong J 2006 Basic mechanisms for the control of germ cell gene expression. Gene 366 39-50.

Ding $X$, Wang $Y$, Zhang D, Wang $Y$, Guo $Z$ \& Zhang $Y 2008$ Increased pre-implantation development of cloned bovine embryos treated with 5-aza-2'. deoxycytidine and trichostatin A. Theriogenology $70622-630$.

Engel N, West AG, Felsenfeld G \& Bartolomei MS 2004 Antagonism between DNA hypermethylation and enhancer-blocking activity at the H19 DMD is uncovered by $\mathrm{CpG}$ mutations. Nature Cenetics 36 883-888.

Epsztejn-Litman S, Feldman N, Abu-Remaileh M, Shufaro Y, Gerson A, Ueda J, Deplus R, Fuks F, Shinkai Y, Cedar H \& Bergman $Y 2008$ De novo DNA methylation promoted by G9a prevents reprogramming of embryonically silenced genes. Nature Structural and Molecular Biology 15 1176-1183.

Estrada J, Sommer J, Collins B, Mir B, Martin A, York A, Petters RM \& Piedrahita JA 2007 Swine created by somatic cell nuclear transfer have increased incidence of intrauterine growth restriction (IUGR). Cloning and Stem Cells 9 229-236.

Farin PW, Piedrahita JA \& Farin CE 2006 Errors in development of fetuses and placentas from in vitro-produced bovine embryos. Theriogenology 65 178-191.

Fernandez-Gonzalez R, Ramirez MA, Bilbao A, De 
Fonseca FR \& Gutierrez-Adan A 2007 Suboptimal in vitro culture conditions: an epigenetic origin of long-term health effects. Molecular Reproduction and Development 74 1149-1156.

Giraldez AJ, Mishima Y, Rihel J, Grocock RJ, Van Dongen S, Inoue K, Enright AJ \& Schier AF 2006 Zebrafish MiR-430 promotes deadenylation and clearance of maternal mRNAs. Science 312 75-79.

Grishok A, Pasquinelli AE, Conte D, Li N, Parrish S, Ha I, Baillie DL, Fire A, Ruvkun G \& Mello CC 2001 Genes and mechanisms related to RNA interference regulate expression of the small temporal RNAs that control C. elegans developmental timing. Cell 106 23-34.

Han DW, Im YB, Do JT, Gupta MK, Uhm S], Kim JH, Scholer HR \& Lee HT 2008 Methylation status of putative differentially methylated regions of porcine 1GF2 and H19. Mol Reprod Dev 75 777-784.

Han 1, Lee Y, Yeom KH, Kim YK, Jin H \& Kim VN 2004 The Drosha-DGCR8 complex in primary microRNA processing. Cenes \& Development 18 3016-3027.

Hansen KH, Bracken AP, Pasini D, Dietrich N, Gehani SS, Monrad A, Rappsilber J, Lerdrup M \& Helin K 2008 A model for transmission of the $\mathrm{H} 3 \mathrm{~K} 27 \mathrm{me} 3$ epigenetic mark. Nature Cell Biology 10 1291-1300.

Hao YH, Mathialagan N, Walters E, Mao JD, Lai LX, Becker D, Li WS, Critser J \& Prather RS 2006 Osteopontin reduces polyspermy during in vitro fertilization of porcine oocytes. Biology of Reproduction 75 726-733.

Huo L.J, Fan H-Y, Liang C-G, Yu L-Z, Zhong ZS, Chen D-Y \& Sun Q-Y 2004 Regulation of ubiquitin-proteaome pathway on pig oocyte meiotic maturation and fertilization. Biology of Reproduction 71 853-862.

Hutvagner G, McLachlan J, Pasquinelli AE, Balint E, Tuschl T \& Zamore PD 2001 A cellular function for the RNA-interference enzyme Dicer in the maturation of the let-7 small temporal RNA. Science 293 834-838.

lager AE, Ragina NP, Ross PJ, Beyhan Z, Cunniff K, Rodriguez RM \& Cibelli JB 2008 Trichostatin A improves histone acefylation in bovine somatic cell nuclear transfer early embryos. Cloning \& Stem Cells $10371-379$.

Jackson RJ \& Standart N 2007 How do microRNAs regulate gene expression? Science STKE 2007 rel.

Jiang H, Bivens NJ, Ries JE, Whitworth KM, Green JA, Forrester LJ, Springer GK, Didion BA, Mathialagan N, Prather RS \& Lucy MC 2001 Constructing CDNA libraries with fewer clones that contain long poly(dA) tails. Biotechniques 31 38-40.

liang $H$, Bivens N, Ries J, Woods R, Whitworth KM, Green JA, Forrester LJ, Springer GK, Mathialagan N, Agca C, Prather RS \& Lucy MC 2004 Large-scale generation and analysis of expression sequence tags from porcine ovary. Biology of Reproduction 71 1991-2002.

Kawahara $Y$, Zinshteyn B, Sethupathy $P$, lizasa $H$, Hatzigeorgiou AG \& Nishikura K 2007 Redirection of silencing targets by adenosine-to-inosine editing of miRNAs. Science 315 1137-1140.
Ketting RF, Fischer SE, Bernstein E, Sijen T, Hannon GJ \& Plasterk RH 2001 Dicer functions in RNA interference and in synthesis of small RNA involved in developmental timing in C. elegans. Cenes \& Development 15 2654-2659.

Kiefer JC 2007 Epigenetics in development. Development Dyn 236 1144-1156.

Klose RJ \& Bird AP 2006 Genomic DNA methylation: the mark and its mediators. Trends in Biochemical Science 31 89-97.

Kouzarides T 2007 Chromatin modifications and their function. Cell 128 693-705.

Lawrence LT \& Moley KH 2008 Epigenetics and assisted reproductive technologies: human imprinting syndromes. Seminaries in Reproductive Medicine 26 143-152.

Lee RC, Feinbaum RL \& Ambros V 1993 The C. elegans heterochronic gene lin- 4 encodes small RNAs with antisense complementarity to lin-14. Cell 75 843-854.

Lee Y, Jeon K, Lee JT, Kim S \& Kim VN 2002 MicroRNA maturation: stepwise processing and subcellular localization. EMBO Journal 21 4663-4670.

Lee $Y$, Ahn C, Han J, Choi H, Kim J, Yim J, Lee J, Provost P, Radmark O, Kim S \& Kim VN 2003 The nuclear RNase III Drosha initiates microRNA processing. Nature 425 415-419.

Li E 2002 Chromatin modification and epigenetic reprogramming in mammalian development [Review]. Nature Reviews Cenetics 3 662-673.

Liu X, Fortin K \& Mourelatos Z 2008 MicroRNAs: biogenesis and molecular functions. Brain Pathology 18 113-21.

Lund E, Guttinger S, Calado A, Dahlberg JE \& Kutay U 2004 Nuclear export of microRNA precursors. Science 303 95-98.

Lykke-Andersen K, Gilchrist MJ, Grabarek JB, Das P, Miska E \& Zernicka-Goetz M 2008 Maternal Argonaute 2 is essential for early mouse development at the maternal-zygotic transition. Molecular Biology \& Cell 19 4383-4392.

Magnani L, Lee K, Fodor WL, Machaty Z \& Cabot RA 2008 Developmental capacity of porcine nuclear transfer embryos correlate with levels of chromatinremodeling transcripts in donor cells. Molecular Reproduction and Developmem 75 766-776.

Mann MR, Lee SS, Doherty AS, Verona RI, Nolen LD, Schultz RM \& Bartolomei MS 2004 Selective loss of imprinting in the placenta following preimplantation development in culture. Development 131 3727-3735.

Mann MRW, Chung YG, Nolen I.D, Verona RI, Latham KE \& Bartolomei MS 2003 Disruption of imprinted gene methylation and expression in cloned preimplantation stage mouse embryos. Biology of Reproduction 69 902-914.

Mizushima N, Levine B, Cuervo AM \& Klionsky J 2008 Autophagy fights disease through cellular self-digestion. Nature 451 1069-1075.

Morgan HD, Santos F, Green K, Dean W \& Reik W 2005 Epigenetic reprogramming in mammals [Review]. Human Molecular Genetics 14 R47-R58. 
Nagano T, Mitchell JA, Sanz LA, Pauler FM, FergusonSmith AC, Feil R \& Fraser P 2008 The Air noncoding RNA epigenetically silences transcription by targeting G9a to chromatin. Science 322 1717-1720.

Neilson JR, Zheng GX, Burge CB \& Sharp PA 2007 Dynamic regulation of miRNA expression in ordered stages of cellular development. Cenes \& Development 21 578-589.

Niemann H, Wrenzycki C, Lucas-Hahn A, Brambrink T, Kues WA \& Carnwath JW 2002 Gene expression patterns in bovine in vitro-produced and nuclear transfer-derived embryos and their implications for early development. Cloning \& Stem Cells 4 29-38.

Nowak-Imialek $M$, Wrenzycki C, Herrmann D, LucasHahn A, Lagutina I, Lemme E, Lazzari G, Galli C \& Niemann H 2008 Messenger RNA expression patterns of histone-associated genes in bovine preimplantation embryos derived from different origins. Molecular Reproduction and Development 75 731-743.

Ooga M, Inoue A, Kageyama S, Akiyama T, Nagata M \& Aoki F 2008 Changes in H3K79 methylation during preimplantation development in mice. Biolology of Reproduction 78 413-24.

Pal S \& Sif S 2007 Interplay between chromatin remodelers and protein arginine methyltransferases. Journal of Cell Physiology 213 306-315.

Pandey RR, Mondal T, Mohammad F, Enroth S, Redrup L, Komorowski J, Nagano T, Mancini-Dinardo D \& Kanduri C $2008 \mathrm{Kcnq} 1$ ot 1 antisense noncoding RNA mediates lineage-specific transcriptional silencing through chromatin-level regulation. Molecular Cell 32 232-246.

Prather RS 1993 Nuclear Control of Early Embryonic Development in Domestic Pigs. Journal of Reproduction and Fertility Supplement 48 17-29.

Prather RS, Hoffman KE, Schoenbeck RA, Stumpf TT \& Li J 1996 Characterization of DNA Synthesis During the 2-Cell Stage and the Production of Tetraploid Chimeric Pig Embryos. Molecular Reproduction and Development 45 38-42.

Rajewsky $\mathbf{N} 2006$ microRNA target predictions in animals. Nature Genetics 38 Supplement S8-13.

Russo VEA, Martienssen RA \& Riggs AD 1996. Epigenetic Mechanisms of Cene Regulation. Woodbury, Cold Spring Harbor Laboratory Press.

Santos F, Hendrich B, Reik W \& Dean W 2002 Dynamic reprogramming of DNA methylation in the early mouse embryo. Developmental Biology 241 172-182.

Santos F, Zakhartchenko V, Stojkovic M, Peters A, Jenuwein T, Wolf E, Reik W \& Dean W 2003 Epigenetic marking correlates with developmental potential in cloned bovine preimplantation embryos. Current Biology $121116-1121$.

Sasaki H, Ishihara K \& Kato R 2000 Mechanisms of Igf2/ H19 imprinting: DNA methylation, chromatin and long-distance gene regulation. Journal of Biochemistry 127711.715.

Schier AF 2007 The maternal-zygotic transition: death and birth of RNAs. Science 316 406-407.
Schoenbeck RA, Peters MS, Rickords LF, Stumpf TT \& Prather RS 1992 Characterization of DNA synthesis and the transition from maternal to embryonic control in the 4-cell porcine embryo. Biology of Reproduction $471118-1125$.

Seggerson K, Tang L \& Moss EG 2002 Two genetic circuits repress the Caenorhabditis elegans heterochronic gene lin-28 after translation initiation. Developmental Biology 243 215-225.

Stark A, Brennecke J, Bushati N, Russell RB \& Cohen SM 2005 Animal MicroRNAs confer robustness to gene expression and have a significant impact on $3^{\prime}$ UTR evolution. Cell 123 1133-1146.

Stitzel M \& Seydoux G 2007 Regulation of the oocyte-tozygote transition. Science 316 407-408.

Strahl BD \& Allis CD 2000 The language of covalent histone modifications. Nature 403 41-45.

Tang F, Kaneda M, O'Carroll D, Hajkova P, Barton SC, Sun YA, Lee C, Tarakhovsky A, Lao K \& Surani MA 2007 Maternal microRNAs are essential for mouse zygotic development. Cenes \& Development 21 644-648.

Telugu BP, Spate L, Prather RS \& Green JA 2009 Acid peptidase activity release from in vitro produced porcine embryos. Molecular Reproduction and Development 76:714-728.

Thomas T, Dixon MP, Kueh AJ \& Voss AK 2008 Mof (MYST1 or KAT8) is essential for progression of embryonic development past the blastocyst stage and required for normal chromatin architecture. Molecular Cell Biology 28 5093-5105.

Tian XC, Park J, Bruno R, French R, Jiang L \& Prather RS 2009 Altered gene expression in cloned piglets. Reproduction Fertility \& Development 21 60-66.

Torres-Padilla ME, Parfitt DE, Kouzarides T \& ZernickaGoetz M 2007 Histone arginine methylation regulates pluripotency in the early mouse embryo. Nature 445 214-218.

Tsukamoto S, Kuma A, Murakami M, Kishi C, Yamamoto A \& Mizushima N 2008 Autophagy is essential for preimplantation development of mouse embryos. Science $321117-120$.

Wang Y, Weng T, Gou D, Chen Z, Chintagari NR \& Liu l. 2007 Identification of rat lung-specific microRNAs by micoRNA microarray: valuable discoveries for the facilitation of lung research. BMC Cenomics 829 .

Watanabe T, Takeda A, Mise K, Okuno T, Suzuki T, Minami N \& Imai H 2005 Stage-specific expression of microRNAs during Xenopus development. FEBS Letters 579 318-324.

Whitworth K, Springer GK, Forrester LJ, Spollen WG, Ries J, Lamberson WL, Bivens N, Murphy CN, Mathialigan N, Green JA \& Prather RS 2004 Developmental expression of 2,489 genes during pig embryogenesis: An EST project. Biology of Reproduction 71 1230-1243.

Whitworth KM, Agca C, Kim JG, Patel RV, Springer GK, Bivens N), Forrester LJ, Mathialagan N, Green JA \& Prather RS 2005 Transcriptional profiling of pig embryogenesis by using a $15-\mathrm{K}$ member unigene 
set specific for pig reproductive tissues and embryos. Biology of Reproduction 72 1437.1451.

Wightman B, Ha I \& Ruvkun G 1993 Posttranscriptional regulation of the heterochronic gene lin- 14 by lin- 4 mediates temporal pattern formation in $C$. elegans. Cell 75 855-862.

Wrenzycki C \& Niemann H 2003 Epigenetic reprogramming in early embryonic development: effects of in-vitro production and somatic nuclear transfer. Reproduction Biomedics Online 7 649-656.

Wrenzycki C, Herrmann D, Gebert C, Carnwath JW \& Niemann H 2006 Gene expression and methylation patterns in cloned embryos. Methods in Molecular Biology 348 285-304.
Zeng Y \& Cullen BR 2003 Sequence requirements for micro RNA processing and function in human cells. RNA 9 112-123.

Zhang B, Wang Q \& Pan X 2007 MicroRNAs and their regulatory roles in animals and plants. Journal or $\mathrm{Cell}$ Physiology 210 279-289.

Zhao $Y$, Ransom JF, L.i A, Vedantham V, von Drehle $M$, Muth AN, Tsuchihashi T, McManus MT, Schwartz RJ \& Srivastava D 2007 Dysregulation of cardiogenesis, cardiac conduction, and cell cycle in mice lacking miRNA-1-2. Cell 129 303-317. 